\title{
Faecal calprotectin in the diagnosis of inflammatory bowel disease
}

\author{
Emanuel Burri*, Christoph Beglinger \\ Department of Gastroenterology and Hepatology, University Hospital Basel, Basel, Switzerland \\ *Corresponding author: burrie@uhbs.ch
}

\begin{abstract}
Suspicion of inflammatory bowel disease should be raised in any patient with chronic or recurrent abdominal pain and diarrhoea. However, symptoms of inflammatory bowel disease (IBD) overlap with functional gastrointestinal disorders and those patients may not need endoscopy. Currently, colonoscopy with multiple biopsies is considered the gold standard to establish the diagnosis of IBD. Unfortunately, patient selection for endoscopy based on symptoms is not reliable. The use of guidelines of appropriateness for endoscopy yields significantly more significant findings but the selection criteria suffer from low specificity.

Calprotectin is a calcium binding protein of neutrophil granulocytes that correlates well with neutrophil infiltration of the intestinal mucosa when measured in faeces. In the last decade, a large body of evidence on the diagnostic value of faecal calprotectin has accumulated and measurement of calprotectin in faeces has been suggested as a surrogate marker of intestinal inflammation. Testing of faecal calprotectin has been highly useful to distinguish organic from functional intestinal disorders in patients with abdominal complaints. Additionally, faecal calprotectin has reliably identified colonic inflammation in patients with suspected IBD. The use of this inexpensive and widely available test in the evaluation and risk stratification in patients with abdominal complaints is likely to increase in the future.
\end{abstract}

Key words: inflammatory bowel disease; faecal calprotectin; diagnostic accuracy

Accepted:September 19, 2011

\section{Introduction}

Abdominal discomfort is a common complaint and presents a clinical challenge even for experienced physicians $(1,2)$. Discomfort may arise from a variety of organic diseases, e.g. inflammatory bowel disease (IBD), and establishing a prompt diagnosis is crucial. However, many patients will suffer from non-organic intestinal disorders, e.g. functional disorders, as it is estimated that $10-20 \%$ of the general population suffer from irritable bowel syndrome (IBS) (3). Accordingly, endoscopy might not be necessary in some patients and the selection of those who should receive prompt endoscopic investigation is crucial in the diagnostic process. The abuse of expensive invasive tests must be balanced against the under-diagnosis of potentially harmful diseases $(4,5)$. Symptoms of
IBD are not exclusive and show a considerable overlap with symptoms of IBS. Therein lays the diagnostic difficulty (6). Suspicion of IBD should always be raised, when patients present with chronic or recurrent episodes of abdominal pain and diarrhoea, especially when alarm signs (rectal bleeding, anorexia, anaemia) are reported (7).

Two major clinical forms of IBD with distinct pathological features exist: ulcerative colitis (UC) and Crohn's disease. The aetiology of the disease is far from being understood but seems to occur mostly in patients in the second to fourth decade with a rising incidence in developed countries. The rapid identification of IBD is crucial as up to $15 \%$ of patients with $C D$ have penetrating lesions (fistulas, phlegmonas, or abcesses) at the time of diagnosis 
(8). The time to diagnosis in general seems to be acceptable, but long delays (> 12 months) exist for a considerable part of patients, especially in CD (9). In children, prompt diagnosis is of special importance as IBD may affect growth and sexual maturation (10).

Currently, colonoscopy with multiple biopsies both from the terminal ileum and the colon, is considered the gold standard to establish the diagnosis of IBD. Unfortunately, patient selection for endoscopy based on symptoms is not reliable $(11,12)$. Both the American Society for Gastroenterological Endoscopy (ASGE) and the European Panel on the Appropriateness of Gastrointestinal Endoscopy (EPAGE) have released guidelines to optimize patient's selection for endoscopy (13-15). In several studies, applying these guidelines significantly yielded more endoscopic findings for appropriate than for inappropriate investigations, but the selection criteria suffered from low specificity $(16,17)$. The evaluation and risk stratification of patients using a simple, non-invasive, and cheap test would therefore be highly desirable. An ideal marker should be sensitive to reliably detect intestinal inflammation and should have reasonable specificity to avoid unnecessary investigations. In fact, measuring calprotectin levels in faeces could fulfil some of these criteria.

\section{Mechanisms of calprotectin during innate immune response}

Calprotectin is a calcium binding protein that is found mainly in neutrophils and to a lesser extent in monocytes and reactive macrophages (18). It belongs to a subgroup of proteins of the $S 100 \mathrm{fa}$ mily (calgranulin A, S100A8; calgranulin B, S100A9 and calgranulin C, S100A12) that is associated with acute/chronic inflammatory disorders and a number of malignancies $(18,19)$. As part of the innate immune system, they provide intra- and extracellular protection during infection and inflammation. Apart from anti-infective host defence mechanisms of S100 proteins, the phagocyte-specific calgranulins have important proinflammatory properties and high concentrations can be found during inflammation both at the sites of infection and in the serum (20). Their release is activated through interaction of activated monocytes with endothelial cells that bind calgranulin on their surface and increase leukocytes recruitment (21). Additionally, proinflammatory chemokines by which phagocytes further promote extravasation of leukocytes to the sites of inflammation are released (22). For a detailed insight on the molecular functions of S100 proteins, we refer to the excellent reviews by Hsu (23) and Manolakis (24).

\section{Distinguishing organic disease from non-organic disorders}

Roesth et al. first reported elevated faecal calprotectin levels in patients with colonic inflammation and colorectal neoplasm almost 20 years ago $(25,26)$. Since then, increased levels of calprotectin have been described in various gastrointestinal diseases: microscopic colitis (27), infectious diarrhea (28), peptic lesions of the upper intestinal tract $(29,30)$, gastric cancer $(26,30)$, and after the use of non-steroidal anti-inflammatory drugs (31). In patients treated for extraintestinal disorders, e.g. rheumatological disorders, the use of corticosteroids or anti-TNF-alpha inhibitors may also influence faecal calprotectin levels through their systemic effect on the intestinal mucosa. It has been shown that in IBD, faecal calprotectin levels dramatically decrease after treatment with either one of these drugs when the intestinal inflammation is restored $(32,33)$.

In recent years, a number of studies have investigated the diagnostic ability of faecal calprotectin to reliably distinguish organic from non-organic gastrointestinal disease in symptomatic patients with lower abdominal complaints $(6,10,29,34-57)$. Table 1 summarizes all studies that evaluated the diagnostic accuracy of faecal calprotectin to identify organic disease. Initially, Tibble et al. investigated 602 patients with symptoms suggestive of IBS or organic intestinal disease that underwent invasive diagnostic imaging with barium enteroclysis, barium enema and/or colonoscopy, as was considered appropriate. Median faecal calprotectin values in patients with organic disease were significantly higher than in patients with non-organic di- 
TABLE 1. Diagnostic accuracy of faecal calprotectin to distinguish between organic and non-organic gastrointestinal disease.

\begin{tabular}{|c|c|c|c|c|c|}
\hline Author & $\begin{array}{c}\text { No. of } \\
\text { patients }\end{array}$ & $\begin{array}{c}\text { Patient } \\
\text { population }\end{array}$ & $\begin{array}{l}\text { Cut-off } \\
(\mu g / g)\end{array}$ & $\begin{array}{c}\text { Sensitivity } \\
\text { (\%) }\end{array}$ & $\begin{array}{c}\text { Specificity } \\
(\%)\end{array}$ \\
\hline Limburg (2000) (35) & 110 & $\mathrm{IBD}, \mathrm{HC}$ & 100 & 83 & 83 \\
\hline Tibble (2000) (36) & 220 & $\mathrm{IBD}, \mathrm{HC}$ & 50 & 82 & 83 \\
\hline Kronborg (2000) (37) & 814 & $\mathrm{CRC}, \mathrm{HC}$ & 50 & 74 & 64 \\
\hline Bunn (2001) (41) & 22 & $\mathrm{IBD}, \mathrm{HC}$ & 31.5 & 100 & 86 \\
\hline Kristinsson $(2001) *(40)$ & 237 & $\mathrm{CRC}, \mathrm{HC}$ & 50 & 47 & 56 \\
\hline Tibble (2001) † (39) & 391 & $\mathrm{IBD}, \mathrm{CRC}, \mathrm{HC}$ & 50 & 79 & 72 \\
\hline Summerton (2002) (29) & 116 & IBD, CRC, IBS, HC & 50 & 82 & 73 \\
\hline Tibble (2002) (6) & 602 & IBD, IBS, HC & 50 & 89 & 79 \\
\hline Costa (2003) (42) & 239 & & 50 & 83 & 82 \\
\hline Carroccio (2003) (43) & 120 & IBD, CRC, IBS, HC & 50 & 66 & 84 \\
\hline Limburg (2003) (45) & 412 & $\mathrm{CRC}, \mathrm{HC}$ & 50 & 37 & 63 \\
\hline Thjodleifsson (2003) (44) & 65 & $\mathrm{IBD}, \mathrm{HC}$ & 50 & 86 & 88 \\
\hline Dolwani (2004) (46) & 148 & IBD, IBS, HC & 60 & 100 & 79 \\
\hline Hoff (2004) (47) & 1534 & $\mathrm{CRC}, \mathrm{HC}$ & 50 & 27 & 76 \\
\hline Berni Canani (2004) (48) & 281 & IBD, IBS, HC & 100 & 74 & 98 \\
\hline Fagerberg (2005) (50) & 36 & $\mathrm{IBD}, \mathrm{HC}$ & 50 & 95 & 93 \\
\hline Bremner (2005) (52) & 100 & IBD, IBS, HC & 50 & 92 & 85 \\
\hline Canani (2006) (10) & 357 & IBD, IBS, HC & 100 & 73 & 98 \\
\hline Garcia Sanchez (2006) (53) & 190 & $\mathrm{IBD}, \mathrm{CRC}, \mathrm{HC}$ & 217 & 85 & 81 \\
\hline D'Inca (2007) (54) & 144 & $\mathrm{IBD}, \mathrm{HC}$ & 50 & 78 & 88 \\
\hline Chung-Faye (2007) (55) & 131 & $\mathrm{IBD}, \mathrm{CRC}$, IBS & 25 & 80 & 74 \\
\hline Jeffrey (2009) (56) & 199 & IBD, IBS & 50 & 93 & 92 \\
\hline Meucci (2010) (57) & 870 & IBD, CRC, IBS, & 50 & 82 & 62 \\
\hline
\end{tabular}

For each study the number of included patients (No. of patients), the patient population and the respective faecal calprotectin cut-off used to define an abnormal test result are given. Sensitivity and specificity indicate the diagnostic ability to distinguish between organic and non-organic intestinal disorders. Sensitivity and specificity to identify colorectal adenoma $(*)$ and any colorectal neoplasm ( $\dagger$ ).

Adapted in parts from Gisbert et al. (58).

IBD - inflammatory bowel disease; CRC - colorectal cancer, IBS - irritable bowel syndrome; HC - healthy controls

sorders (50 mg/L vs. $4 \mathrm{mg} / \mathrm{L}, \mathrm{P}<0.001)$. To distinguish between the two groups of patients, faecal calprotectin had $89 \%$ sensitivity and $79 \%$ specificity (23). In a recent meta-analysis combining data from 2475 patients, these initial results by Tibble et al. were again confirmed. Gisbert et al. calculated a mean sensitivity of $83 \%$ and mean specificity of $84 \%$ for faecal calprotectin to distinguish organic and non-organic disease (58). The diagnostic accuracy was higher than for C-reactive protein (CRP), erythrocyte sedimentation rate (ESR), or a combination of both $(6,36)$. A recent prospective multi- center study by Meucci et al. expanded the use of faecal calprotectin to a population with unselected patients (57). The study included 870 consecutive patients referred for colonoscopy for any reason to one of five participating centres. In this unselected group of patients, mean sensitivity of faecal calprotectin to detect any organic disease remained high (89\%) but specificity $(62 \%)$ was somewhat lower than previously published. When subgroups of patients were analyzed, test sensitivity and specificity varied considerably: To detect any organic disease in patients with chronic diarr- 
hea ( $N=43,100 \%$ and $79 \%$, respectively), to detect any organic disease in patients with lower gastrointestinal bleeding or abnormal barium enema ( $N=156,81 \%$ and 60 , respectively), to detect colorectal cancer in patients with altered bowel habits ( $N=135,100 \%$ and $57 \%$, respectively), and to detect colorectal cancer or polyps $>0.9 \mathrm{~cm}$ in diameter in patients referred for screening colonoscopy ( $N=247,56 \%$ and $67 \%$, respectively).

\section{Diagnostic value of faecal calprotectin to identify IBD}

Measuring leukocytes in faeces has long been the only available non-invasive stool biomarker to assess colonic inflammation, but the technical difficulties of the test hindered its widespread use. Stool samples had to be analyzed immediately to avoid cell dissolution and furthermore, measuring leukocytes in faeces provided only semi-quantitative test results. The clinical utility of this stool marker has therefore been limited. Faecal calprotectin on the other hand correlates well with neutrophil infiltration of the intestinal mucosa and is resistant to enzymatic degradation both in vivo and in vitro (59). The distribution of calprotectin is homogenous within stool samples $(60,61)$ and concentrations from single samples correlate well with those from corresponding four days collections $(36,62)$. Dietary restrictions are not necessary prior to collecting a sample (60). There is only limited data on the effect of intestinal blood loss on calprotectin values, but data suggest that in the absence of overt hematochezia, faecal calprotectin values are not significantly increased by intestinal blood $(39,63)$. Calprotectin is resistant to proteolytic degradation and is stable at room temperature for up to seven days in stool samples (25).

A number of studies have reported higher faecal calprotectin levels in patients with IBD compared to IBS patients or healthy controls $(6,10,25,29,35$, $36,38,41-44,46,48,51,54,55,59,64-74)$. Table 2 summarizes all studies that investigated the diagnostic performance of faecal calprotectin to detect IBD. Gisbert et al. calculated a pooled sensitivity and specificity of $80 \%$ and $76 \%$, respectively, to identify IBD from data of 754 patients. From this data, slightly higher diagnostic accuracy was calculated for CD (sensitivity $83 \%$, specificity $85 \%$ ) than for UC (sensitivity $72 \%$, specificity $74 \%$ ). Recently a metaanalysis by von Roon et al. (19) summarized data of 5983 patients from 30 studies (25,26,29,35-52, $59,62,64,75,76)$. In IBD patients, higher faecal calprotectin levels was reported than in non-IBD patients, which translated into an excellent mean sensitivity and specificity of $95 \%$ and $91 \%$, respectively, to distinguish between them. Higher calprotectin levels were reported for CD than for UC ( $P=$ 0.04), but the difference did not allow separating the two disorders $(6,10,51)$.

To determine, if the use of faecal calprotectin may reduce the number of endoscopies in patients with suspected IBD, data from 13 studies $(10,35,36$, $41,50,68,69,71-74,77,78)$ including a total of 1041 patients (670 adults, 371 children) were recently summarized in an excellent meta-analysis by van Rheenen et al. (79). All studies prospectively investigated the diagnostic accuracy of faecal calprotectin in patients with clinically suspected IBD that had to be confirmed histopathologically. Pooled sensitivity and specificity of calprotectin testing was $93 \%$ and $96 \%$, respectively. Specificity in children and teenagers was significantly lower (76\%). In adults, using faecal calprotectin as a screening test in suspected IBD to decide upon the need for endoscopy would result in a $67 \%$ reduction of patients requiring endoscopy, but would result in delayed diagnosis of IBD in $6 \%$ of patients because of false negative test result.

C-reactive protein has long been the best-established biomarker in IBD (80) and other serum-based biomarkers (a1-acid glycoprotein, serum amyloid A-protein (SAA), $a_{2}$-globulin, thrombopoietin) appear to be inferior to, or less validated, than CRP (81). Serum calprotectin seems to correlate with active IBD (82) and elevated serum and mucosal calprotectin values have been reported in patients with active disease $(83,84)$. However, the diagnostic accuracy of faecal calprotectin to diagnose IBD is superior to CRP and ESR, to serological markers such as anti-neutrophil cytoplasmatic antibody (ANCA) and anti-Saccharomyces cerevisiae antibody (ASCA) and also to serum measurement of calprotectin (72). The main advantage of faecal bio- 
TABLE 2. Diagnostic accuracy of faecal calprotectin to distinguish inflammatory bowel disease (IBD) from non-IBD.

\begin{tabular}{|c|c|c|c|c|}
\hline Author & $\begin{array}{c}\text { No. of } \\
\text { patients }\end{array}$ & $\begin{array}{c}\text { Patient } \\
\text { population }\end{array}$ & $\begin{array}{c}\text { Sensitivity } \\
(\%)\end{array}$ & $\begin{array}{c}\text { Specificity } \\
\text { (\%) }\end{array}$ \\
\hline Limburg (2000) (35) & 110 & UC/CD & 94 & 83 \\
\hline Tibble (2000) (36) & 220 & $C D$ & 100 & 97 \\
\hline Bunn (2001) (41) & 68 & UC/CD & 65 & 100 \\
\hline Summerton (2002) (29) & 116 & $\mathrm{UC/CD}$ & 79 & n.a. \\
\hline Costa (2003) (42) & 239 & UC/CD & 81 & 82 \\
\hline Carroccio (2003) (43) & 70 & $C D$ & 100 & 95 \\
\hline Langhorst (2005) (66) & 31 & UC & 92 & 63 \\
\hline Silberer (2005) (51) & 119 & UC/CD & 61 & n.a. \\
\hline Canani (2006) (10) & 27 & UC/CD & 93 & 89 \\
\hline D'Inca (2007) (54) & 144 & UC/CD & 78 & 83 \\
\hline Chung-Faye (2007) (55) & 148 & UC/CD & 78 & 90 \\
\hline Kaiser (2007) (67) & 171 & UC/CD & 63 & 86 \\
\hline Schroder (2007) (68) & 88 & UC/CD & 93 & 100 \\
\hline Langhorst (2008) (70) & 139 & UC/CD & 100 & 37 \\
\hline Otten (2008) (71) * & 114 & UC/CD & 100 & n.a. \\
\hline Schoepfer (2008) (72) & 136 & UC/CD & 83 & 100 \\
\hline Sidler (2008) (73) & 61 & UC/CD & 100 & 64 \\
\hline \multicolumn{5}{|c|}{$\begin{array}{l}\text { For each study the number of included patients (No. of patients) and the type of inflammatory bowel disease (IBD) of } \\
\text { the patient population is given: Ulcerative colitis (UC) or Crohn's disease (CD), or both (UC/CD). Sensitivity and specificity } \\
\text { indicate the diagnostic ability to distinguish between IBD and non-IBD. } \\
\text { *A rapid test for calprotectin measurement was used. } \\
\text { Adapted in parts from Gisbert et al. (58). } \\
\text { n.a. - not available }\end{array}$} \\
\hline
\end{tabular}

markers is that the faecal stream is in direct contact with the mucosa and therefore, when measured in faeces, calprotectin detects inflammatory conditions far more precisely than biomarkers measured in serum $(25,85)$.

\section{Clinical use of faecal calprotectin}

When using faecal calprotectin in clinical practice, it is important to understand, that it is not a disease-specific marker for IBD but rather a marker of mucosal damage. Elevated values have been described in a number of clinical conditions other than IBD (25-31) and to rely solely on faecal calprotectin to diagnose IBD would prove misleading. Important biological variability has been reported for faecal calprotectin measurements on different days $(86,87)$ and calprotectin levels seem to fluc- tuate depending on disease location (67). In Crohn's disease the release of calprotectin from site of ileal inflammation has been greater than from the inflamed colon (88). Furthermore, it should be mentioned, that in several important gastrointestinal disorders, such as small bowel bacterial overgrowth, celiac disease, or lactose intolerance, calprotectin levels will be normal $(89,90)$. Although faecal calprotectin has been established as a valid marker of intestinal inflammation in recent years, these limiting factors have to be kept in mind when investigating a patient with suspected IBD.

When comparing data from different studies investigating the diagnostic ability of faecal calprotectin in IBD, the use of the same cut-off to allocate a "positive" or "negative" test results would be preferable. Among the available literature, published cut-off concentrations for faecal calprotectin 
vary from 18.6 to $250 \mu \mathrm{g} / \mathrm{g}(51,62)$. Currently, the recommended cut-off level provided by manufacturers indicating an abnormal test results is $50 \mu \mathrm{g}$ calprotectin per gramm of faeces. However, it might be useful to use different cut-offs depending on the clinical situation that the test is being applied. Higher values have been suggested for patients with known inflammatory conditions while lower values might be appropriate to rule out patients with IBS $(42,54)$. The use of a low cut-off would assure clinicians in their decision to avoid unnecessary endoscopies in the evaluation of patients with abdominal complaints (42).

\section{Summary}

Inflammatory bowel disease is a lifelong disorder of chronic inflammation that should be suspected in all patients with chronic or recurrent episodes of abdominal pain. The clinical features of UC and CD are distinct, but symptoms may not only overlap among them, but also with other non-IBD disorders, such as IBS.

Endoscopy with histopathological confirmation is the current gold standard for the diagnosis of IBD.

\section{References}

1. Kay $L$, Jorgensen $T$. Abdominal symptom associations in a longitudinal study. Int J Epidemiol 1993;22:1093-100.

2. Kay $L$, Jorgensen $T$, Schultz-Larsen K. Abdominal pain in a 70-year-old Danish population. An epidemiological study of the prevalence and importance of abdominal pain. $J$ Clin Epidemiol 1992;45:1377-82.

3. Hillila MT, Farkkila MA. Prevalence of irritable bowel syndrome according to different diagnostic criteria in a non-selected adult population. Aliment Pharmacol Ther 2004;20:339-45.

4. Costa F, Mumolo MG, Marchi S, Bellini M. Differential diagnosis between functional and organic intestinal disorders: is there a role for non-invasive tests? World J Gastroenterol 2007;13:219-23.

5. Tack J, Talley NJ, Camilleri M, Holtmann G, Hu P, Malagelada J-R, et al. Functional gastroduodenal disorders. Gastroenterology 2006;130:1466-79.

6. Tibble JA, Sigthorsson G, Foster R, Forgacs I, Bjarnason I. Use of surrogate markers of inflammation and Rome criteria to distinguish organic from nonorganic intestinal disease. Gastroenterology 2002;123:450-60.
However, endoscopy is invasive, costly, and often not much appreciated by patients. Measurement of faecal calprotectin has been shown to reliably differentiate IBD from IBS and has been proven especially useful in ruling out IBD in undiagnosed, symptomatic patients. The use of faecal calprotectin as a screening test in suspected IBD would result in a considerable reduction of patients requiring endoscopy.

More work needs to be done to further define the value of faecal calprotectin measurement as a diagnostic test in different clinical settings, e.g. asymptomatic patients vs. symptomatic patients, and to establish clinically useful cut-off levels to define an abnormal test result for a given setting. Furthermore, the short- and long-term outcome as well as the cost-effectiveness of a faecal calprotectin-based diagnostic approach to patients with abdominal complaints has to be further investigated.

In conclusion, measurement of faecal calprotectin is highly useful for the diagnosis of IBD and may serve as a surrogate marker of mucosal inflammation throughout the intestinal tract.

\section{Potential conflict of interest}

None declared.

7. Stange EF, Travis SP, Vermeire S, Beglinger $C$, Kupcinkas $L$, Geboes K, et al. European evidence based consensus on the diagnosis and management of Crohn's disease: definitions and diagnosis. Gut 2006;55 (Suppl 1):i1-15.

8. Bruining DH, Siddiki HA, Fletcher JG, Tremaine WJ, Sandborn WJ, Loftus EV, Jr. Prevalence of penetrating disease and extraintestinal manifestations of Crohn's disease detected with CT enterography. Inflamm Bowel Dis 2008;14:1701-6.

9. Vavricka SR, Spigaglia SM, Rogler G, Pittet V, Michetti P, Felley $C$, et al. Systematic evaluation of risk factors for diagnostic delay in inflammatory bowel disease. Inflamm Bowel Dis 2011; in press.

10. Canani RB, de Horatio LT, Terrin G, Romano MT, Miele E, Staiano A, et al. Combined use of noninvasive tests is useful in the initial diagnostic approach to a child with suspected inflammatory bowel disease. J Pediatr Gastroenterol Nutr 2006;42:9-15.

11. Group TDDS. Value of the unaided clinical diagnosis in dyspeptic patients in primary care. Am J Gastroenterol 2001;96:1417-21. 
12. Jellema $P$, van der Windt DAWM, Schellevis FG, van der Horst HE. Systematic review: accuracy of symptom-based criteria for diagnosis of irritable bowel syndrome in primary care. Alimentary Pharmacology \& Therapeutics 2009;30:695-706.

13. Vader JP, Burnand B, Froehlich F, Dubois RW, Bochud $M$, Gonvers JJ. The European Panel on Appropriateness of Gastrointestinal Endoscopy (EPAGE): project and methods. Endoscopy 1999;31:572-8.

14. Juillerat P, Peytremann-Bridevaux I, Vader JP, Arditi C, Schussele Filliettaz S, Dubois RW, et al. Appropriateness of colonoscopy in Europe (EPAGE II). Presentation of methodology, general results, and analysis of complications. Endoscopy 2009;41:240-6.

15. Appropriate use of gastrointestinal endoscopy. American Society for Gastrointestinal Endoscopy. Gastrointest Endosc 2000;52:831-7.

16. Chan YM, Goh KL. Appropriateness and diagnostic yield of EGD: a prospective study in a large Asian hospital. Gastrointest Endosc 2004;59:517-24.

17. Grassini M, Verna C, Niola P, Navino M, Battaglia E, Bassotti G. Appropriateness of colonoscopy: diagnostic yield and safety in guidelines. World J Gastroenterol 2007;13:1816-9; discussion 9.

18. Foell D, Frosch M, Sorg C, Roth J. Phagocyte-specific calciu$m$-binding $S 100$ proteins as clinical laboratory markers of inflammation. Clin Chim Acta 2004;344:37-51.

19. von Roon AC, Karamountzos L, Purkayastha S, Reese GE, Darzi AW, Teare JP, et al. Diagnostic precision of fecal calprotectin for inflammatory bowel disease and colorectal malignancy. Am J Gastroenterol 2007;102:803-13.

20. Foell $D$, Roth J. Proinflammatory $\$ 100$ proteins in arthritis and autoimmune disease. Arthritis Rheum 2004;50:3762-71.

21. Srikrishna G, Panneerselvam K, Westphal V, Abraham V, Varki A, Freeze HH. Two proteins modulating transendothelial migration of leukocytes recognize novel carboxylated glycans on endothelial cells. J Immunol 2001;166:4678-88.

22. Ryckman C, Vandal K, Rouleau P, Talbot M, Tessier PA. Proinflammatory activities of S100: proteins S100A8, S100A9, and S100A8/A9 induce neutrophil chemotaxis and adhesion. J Immunol 2003; 170:3233-42.

23. Hsu K, Champaiboon C, Guenther BD, Sorenson BS, Khammanivong A, Ross KF, et al. Anti-Infective Protective Properties of 5100 Calgranulins. Antiinflamm Antiallergy Agents Med Chem 2009;8:290-305.

24. Manolakis AC, Kapsoritakis AN, Tiaka EK, Potamianos SP. Calprotectin, calgranulin C, and other members of the $s 100$ protein family in inflammatory bowel disease. Dig Dis Sci 2011;56:1601-11.

25. Roseth AG, Fagerhol MK, Aadland E, Schjonsby H. Assessment of the neutrophil dominating protein calprotectin in feces. A methodologic study. Scand J Gastroenterol 1992;27:793-8.

26. Roseth AG, Kristinsson J, Fagerhol MK, Schjonsby H, Aadland $E$, Nygaard K, et al. Faecal calprotectin: a novel test for the diagnosis of colorectal cancer? Scand J Gastroenterol 1993;28:1073-6.

27. Wildt S, Nordgaard-Lassen I, Bendtsen F, Rumessen JJ. Metabolic and inflammatory faecal markers in collagenous colitis. Eur J Gastroenterol Hepatol 2007; 19:567-74.
28. Shastri $Y M$, Bergis D, Povse N, Schäfer $V$, Shastri S, Weindel $M$, et al. Prospective multicenter study evaluating fecal calprotectin in adult acute bacterial diarrhea. Am J Med 2008; 121:1099-106.

29. Summerton CB, Longlands MG, Wiener K, Shreeve DR. Faecal calprotectin: a marker of inflammation throughout the intestinal tract. Eur J Gastroenterol Hepatol 2002;14:841-5.

30. Manz M, Burri E, Niederberger $C$, Rothen $C$, Beglinger $C$. Faecal calprotectin predicts upper gastrointestinal pathology. Gut 2009;58 (Suppl II).

31. Maiden L, Thjodleifsson B, Theodors A, Gonzalez J, Bjarnason I. A quantitative analysis of NSAID-induced small bowel pathology by capsule enteroscopy. Gastroenterology 2005;128:1172-8.

32. Sipponen $T$, Savilahti $E$, Kolho KL, Nuutinen $H$, Turunen $U$, Farkkila M. Crohn's disease activity assessed by fecal calprotectin and lactoferrin: correlation with Crohn's disease activity index and endoscopic findings. Inflamm Bowel Dis 2008;14:40-6.

33. Wagner $M$, Peterson CGB, Ridefelt $P$, Sangfelt $P$, Carlson $M$. Fecal markers of inflammation used as surrogate markers for treatment outcome in relapsing inflammatory bowel disease. World J Gastroenterol 2008;14:5584-9; discussion 8.

34. Tibble JA, Sigthorsson G, Foster $R$, Scott D, Fagerhol MK, Roseth $A$, et al. High prevalence of NSAID enteropathy as shown by a simple faecal test. Gut 1999;45:362-6.

35. Limburg PJ, Ahlquist DA, Sandborn WJ, Mahoney DW, Devens $M E$, Harrington JJ, et al. Fecal calprotectin levels predict colorectal inflammation among patients with chronic diarrhea referred for colonoscopy. Am J Gastroenterol 2000;95:2831-7.

36. Tibble J, Teahon $K$, Thjodleifsson B, Roseth A, Sigthorsson $G$, Bridger $S$, et al. A simple method for assessing intestinal in flammation in Crohn's disease. Gut 2000;47:506-13.

37. Kronborg O, Ugstad M, Fuglerud P, Johne B, Hardcastle J, Scholefield JH, et al. Faecal calprotectin levels in a high risk population for colorectal neoplasia. Gut 2000;46:795-800.

38. Bunn SK, Bisset WM, Main MJ, Golden BE. Fecal calprotectin as a measure of disease activity in childhood inflammatory bowel disease. J Pediatr Gastroenterol Nutr 2001;32:171-7.

39. Tibble J, Sigthorsson G, Foster R, Sherwood R, Fagerhol M, Bjarnason I. Faecal calprotectin and faecal occult blood tests in the diagnosis of colorectal carcinoma and adenoma. Gut 2001;49:402-8.

40. Kristinsson J, Nygaard K, Aadland E, Barstad S, Sauar J, Hofstad $B$, et al. Screening of first degree relatives of patients operated for colorectal cancer: evaluation of fecal calprotectin vs. hemoccult II. Digestion 2001;64:104-10.

41. Bunn SK, Bisset WM, Main MJ, Gray ES, Olson S, Golden BE. Fecal calprotectin: validation as a noninvasive measure of bowel inflammation in childhood inflammatory bowel disease. J Pediatr Gastroenterol Nutr 2001;33:14-22.

42. Costa F, Mumolo MG, Bellini M, Romano MR, Ceccarelli L, Arpe $P$, et al. Role of faecal calprotectin as non-invasive marker of intestinal inflammation. Dig Liver Dis 2003;35:642-7.

43. Carroccio A, lacono G, Cottone M, Di Prima L, Cartabellotta $F$, Cavataio F, et al. Diagnostic accuracy of fecal calprotectin assay in distinguishing organic causes of chronic diarrhea from irritable bowel syndrome: a prospective study in adults and children. Clin Chem 2003;49:861-7. 
44. Thjodleifsson B, Sigthorsson G, Cariglia N, Reynisdottir I, Gudbjartsson DF, Kristjansson K, et al. Subclinical intestinal inflammation: an inherited abnormality in Crohn's disease relatives? Gastroenterology 2003;124:1728-37.

45. Limburg PJ, Devens ME, Harrington JJ, DiehI NN, Mahoney DW, Ahlquist DA. Prospective evaluation of fecal calprotectin as a screening biomarker for colorectal neoplasia. Am J Gastroenterol 2003;98:2299-305.

46. Dolwani S, Metzner M, Wassell JJ, Yong A, Hawthorne AB. Diagnostic accuracy of faecal calprotectin estimation in prediction of abnormal small bowel radiology. Aliment Pharmacol Ther 2004;20:615-21.

47. Hoff G, Grotmol T, Thiis-Evensen E, Bretthauer M, Gondal G, Vatn MH. Testing for faecal calprotectin (PhiCal) in the Norwegian Colorectal Cancer Prevention trial on flexible sigmoidoscopy screening: comparison with an immunochemical test for occult blood (FlexSure OBT). Gut 2004;53:1329-33.

48. Berni Canani R, Rapacciuolo L, Romano MT, Tanturri de Horatio $L$, Terrin $G$, Manguso F, et al. Diagnostic value of faecal calprotectin in paediatric gastroenterology clinical practice. Dig Liver Dis 2004;36:467-70.

49. Wassell J, Dolwani S, Metzner M, Losty H, Hawthorne A. Faecal calprotectin: a new marker for Crohn's disease? Ann Clin Biochem 2004;41:230-2.

50. Fagerberg UL, Loof L, Myrdal U, Hansson LO, Finkel Y. Colorectal inflammation is well predicted by fecal calprotectin in children with gastrointestinal symptoms. J Pediatr Gastroenterol Nutr 2005;40:450-5.

51. Silberer $H$, Kuppers B, Mickisch O, Baniewicz W, Drescher $M$, Traber $L$, et al. Fecal leukocyte proteins in inflammatory bowel disease and irritable bowel syndrome. Clin Lab 2005;51:117-26.

52. Bremner A, Roked S, Robinson R, Phillips I, Beattie M. Faecal calprotectin in children with chronic gastrointestinal symptoms. Acta Paediatr 2005;94:1855-8.

53. Garcia Sanchez Mdel V, Gonzalez R, Iglesias Flores E, Gomez Camacho F, Casais Juanena L, Cerezo Ruiz A, et al. [Diagnostic value of fecal calprotectin in predicting an $a b$ normal colonoscopy]. Med Clin (Barc) 2006;127:41-6.

54. D'Incà R, Dal Pont E, Di Leo V, Ferronato A, Fries W, Vettorato $M G$, et al. Calprotectin and lactoferrin in the assessment of intestinal inflammation and organic disease. Int J Colorectal Dis 2007;22:429-37.

55. Chung-Faye G, Hayee B, Maestranzi S, Donaldson N, ForgaCs I, Sherwood R. Fecal M2-pyruvate kinase (M2-PK): a novel marker of intestinal inflammation. Inflamm Bowel Dis 2007;13:1374-8.

56. Jeffery J, Lewis SJ, Ayling RM. Fecal dimeric M2-pyruvate kinase (tumor M2-PK) in the differential diagnosis of functional and organic bowel disorders. Inflamm Bowel Dis 2009;15:1630-4.

57. Meucci G, D'Inca R, Maieron R, Orzes N, Vecchi M, Visentini $D$, et al. Diagnostic value of faecal calprotectin in unselected outpatients referred for colonoscopy: A multicenter prospective study. Dig Liver Dis 2010;42:191-5.

58. Gisbert JP, McNicholl AG. Questions and answers on the role of faecal calprotectin as a biological marker in inflammatory bowel disease. Dig Liver Dis 2009;41:56-66.
59. Roseth AG, Schmidt PN, Fagerhol MK. Correlation between faecal excretion of indium-111-labelled granulocytes and calprotectin, a granulocyte marker protein, in patients with inflammatory bowel disease. Scand J Gastroenterol 1999;34:50-4.

60. Ton H, Brandsnes, Dale S, Holtlund J, Skuibina E, Schjonsby $H$, et al. Improved assay for fecal calprotectin. Clin Chim Acta 2000;292:41-54.

61. Kristinsson J, Armbruster CH, Ugstad M, Kriwanek S, Nygaa$r d \mathrm{~K}$, Ton $\mathrm{H}$, et al. Fecal excretion of calprotectin in colorectal cancer: relationship to tumor characteristics. Scand J Gastroenterol 2001;36:202-7.

62. Tibble JA, Sigthorsson G, Bridger S, Fagerhol MK, Bjarnason I. Surrogate markers of intestinal inflammation are predictive of relapse in patients with inflammatory bowel disease. Gastroenterology 2000;119:15-22.

63. van der Sluijs Veer $G$, van den Hoven $B$, Russel MG, van den Bergh FA. Time-resolved fluorimetric immunoassay of calprotectin: technical and clinical aspects in diagnosis of inflammatory bowel diseases. Clin Chem Lab Med 2006;44:292-8.

64. Roseth AG, Aadland E, Jahnsen J, Raknerud N. Assessment of disease activity in ulcerative colitis by faecal calprotectin, a novel granulocyte marker protein. Digestion 1997;58:176-80.

65. Fagerberg UL, Lööf L, Merzoug RD, Hansson L-O, Finkel Y. Fecal calprotectin levels in healthy children studied with an improved assay. J Pediatr Gastroenterol Nutr 2003;37:468-72.

66. Langhorst J, Elsenbruch S, Mueller T, Rueffer A, Spahn G, Michalsen $A$, et al. Comparison of 4 neutrophil-derived proteins in feces as indicators of disease activity in ulcerative colitis. Inflamm Bowel Dis 2005;11:1085-91.

67. Kaiser T, Langhorst J, Wittkowski H, Becker K, Friedrich AW, Rueffer $A$, et al. Faecal S100A12 as a non-invasive marker distinguishing inflammatory bowel disease from irritable bowel syndrome. Gut 2007;56:1706-13.

68. Schroder O, Naumann M, Shastri Y, Povse N, Stein J. Prospective evaluation of faecal neutrophil-derived proteins in identifying intestinal inflammation: combination of parameters does not improve diagnostic accuracy of calprotectin. Aliment Pharmacol Ther 2007;26:1035-42.

69. Schoepfer AM, Trummler M, Seeholzer P, Criblez DH, SeiboId F. Accuracy of four fecal assays in the diagnosis of colitis. Dis Colon Rectum 2007;50:1697-706.

70. Langhorst J, Elsenbruch S, Koelzer J, Rueffer A, Michalsen $A$, Dobos GJ. Noninvasive markers in the assessment of intestinal inflammation in inflammatory bowel diseases: performance of fecal lactoferrin, calprotectin, and $P M N$-elastase, CRP, and clinical indices. Am J Gastroenterol 2008; 103:162-9.

71. Otten CM, Kok L, Witteman BJ, Baumgarten R, Kampman $E$, Moons KG, et al. Diagnostic performance of rapid tests for detection of fecal calprotectin and lactoferrin and their ability to discriminate inflammatory from irritable bowel syndrome. Clin Chem Lab Med 2008;46:1275-80.

72. Schoepfer AM, Trummler M, Seeholzer P, Seibold-Schmid B, Seibold F. Discriminating IBD from IBS: comparison of the test performance of fecal markers, blood leukocytes, CRP, and IBD antibodies. Inflamm Bowel Dis 2008; 14:32-9.

73. Sidler MA, Leach ST, Day AS. Fecal S100A12 and fecal calprotectin as noninvasive markers for inflammatory bowel disease in children. Inflamm Bowel Dis 2008;14:359-66. 
74. Ashorn S, Honkanen T, Kolho KL, Ashorn M, Valineva T, Wei $B$, et al. Fecal calprotectin levels and serological responses to microbial antigens among children and adolescents with inflammatory bowel disease. Inflamm Bowel Dis 2009; 15:199-205.

75. Costa F, Mumolo MG, Ceccarelli L, Bellini M, Romano MR, Sterpi $C$, et al. Calprotectin is a stronger predictive marker of relapse in ulcerative colitis than in Crohn's disease. Gut 2005;54:364-8.

76. Gaya DR, Lyon TD, Duncan A, Neilly JB, Han S, Howell J, et al. Faecal calprotectin in the assessment of Crohn's disease activity. QJM 2005;98:435-41.

77. Perminow G, Brackmann S, Lyckander LG, Franke A, Borthne $A$, Rydning A, et al. A characterization in childhood inflammatory bowel disease, a new population-based inception cohort from South-Eastern Norway, 2005-07, showing increased incidence in Crohn's disease. Scand J Gastroenterol 2009; 44:446-56.

78. Kolho KL, Raivio T, Lindahl H, Savilahti E. Fecal calprotectin remains high during glucocorticoid therapy in children with inflammatory bowel disease. Scand J Gastroenterol 2006;41:720-5.

79. van Rheenen PF, Van de Vijver E, Fidler V. Faecal calprotectin for screening of patients with suspected inflammatory bowel disease: diagnostic meta-analysis. BMJ 2010;341:c3369.

80. Vermeire S, Van Assche G, Rutgeerts P. C-reactive protein as a marker for inflammatory bowel disease. Inflamm Bowel Dis 2004;10:661-5.

81. Palmon R, Brown SJ, Abreu MT. What is the role and significance of serum and stool biomarkers in the diagnosis of IBD? Inflamm Bowel Dis 2008;14 Suppl 2:S187-9.

82. Lugering N, Stoll R, Kucharzik T, Schmid KW, Rohlmann G, Burmeister $G$, et al. Immunohistochemical distribution and serum levels of the $\mathrm{Ca}(2+)$-binding proteins MRP8, MRP14 and their heterodimeric form MRP8/14 in Crohn's disease. Digestion 1995;56:406-14.
83. Foell D, Kucharzik T, Kraft M, VogIT, Sorg C, Domschke W, et al. Neutrophil derived human S100A12 (EN-RAGE) is strongly expressed during chronic active inflammatory bowel disease. Gut 2003;52:847-53.

84. Leach ST, Yang Z, Messina I, Song C, Geczy CL, Cunningham $A M$, et al. Serum and mucosal S100 proteins, calprotectin (S100A8/S100A9) and S100A12, are elevated at diagnosis in children with inflammatory bowel disease. Scand J Gastroenterol 2007;42:1321-31.

85. Manolakis AC, Kapsoritakis AN, Georgoulias P, Tzavara C, Valotassiou V, Kapsoritaki A, et al. Moderate performance of serum S100A12, in distinguishing inflammatory bowel disease from irritable bowel syndrome. BMC Gastroenterol 2010;10:118.

86. Moum B, Jahnsen J, Bernklev T. Fecal calprotectin variability in Crohn's disease. Inflamm Bowel Dis 2010;16:1091-2.

87. Husebye $E$, Tøn $H$, Johne B. Biological variability of fecal calprotectin in patients referred for colonoscopy without colonic inflammation or neoplasm. Am J Gastroenterol 2001;96:2683-7.

88. Foell D, Wittkowski H, Ren Z, Turton J, Pang G, Daebritz J, et al. Phagocyte-specific $S 100$ proteins are released from af fected mucosa and promote immune responses during inflammatory bowel disease. J Pathol 2008;216:183-92.

89. Montalto M, Santoro L, Dalvai S, Curigliano V, D'onofrio F, Scarpellini $E$, et al. Fecal calprotectin concentrations in patients with small intestinal bacterial overgrowth. Digestive diseases (Basel, Switzerland) 2008;26:183-6.

90. Montalto $M$, Santoro L, Curigliano V, D'onofrio F, Cammarota $G$, Panunzi $S$, et al. Faecal calprotectin concentrations in untreated coeliac patients. Scand J Gastroenterol 2007:42:957-61.

\section{Fekalni kalprotektin u dijagnozi upalne bolesti crijeva}

\section{Sažetak}

Kod svakog bolesnika s kroničnom ili rekurentnom abdominalnom boli i proljevom potrebno je posumnjati na upalnu bolest crijeva. Međutim simptomi upalne bolesti crijeva (engl. inflammatory bowel disease, IBD) preklapaju se s funkcionalnim gastrointestinalnim poremećajima te je moguće da ti bolesnici ne trebaju endoskopiju. Trenutno se kolonoskopija s višestrukim biopsijama smatra zlatnim standardom u postavljanju dijagnoze IBD. Nažalost, odabir bolesnika za endoskopiju temeljen na simptomima nije pouzdan. Smjernice za određivanje primjerenosti endoskopije daju statistički značajno više značajnih rezultata, međutim primjena ovih kriterija ima nisku specifičnost.

Kalprotektin je protein neutrofilnih granulocita koji veže kalcij te je pri određivanju koncentracije iz stolice u dobroj korelaciji s neutrofilnom infiltracijom crijevne sluznice. U zadnjih je deset godina sakupljen veliki broj dokaza o dijagnostičkoj vrijednosti određivanja koncentracije fekalnog kalprotektina te je ono predloženo kao zamjenski biljeg crijevne upale. Određivanje koncentracije fekalnog kalprotektina vrlo je korisno u razlikovanju organskih od funkcionalnih crijevnih poremećaja kod bolesnika s abdominalnim tegobama. K tome se još određivanjem koncentracije fekalnog kalprotektina pouzdano otkriva upala debelog crijeva kod bolesnika za koje se sumnjalo da su oboljeli od IBD. Primjena ovog ekonomski povoljnog i vrlo dostupnog testa pri procjeni i stratifikaciji rizika kod bolesnika s abdominalnim tegobama vjerojatno će porasti u budućnosti.

Ključne riječi: upalna bolest crijeva; fekalni kalprotektin; dijagnostička točnost 